\title{
SISTEM INFORMASI PEMASANGAN LISTRIK PRABAYAR BARU
}

\section{Dahlan Abdullah dan Khairullah}

Program Studi Teknik Informatika, Fakultas Teknik, Universitas Malikussaleh, Aceh, Indonesia

${ }^{*}$ Corresponding Author: dahlan@unimal.ac.id

\begin{abstract}
Abstrak - PT PLN (Persero) Rayon Lhoksukon ini membutuhkan sarana dan prasarana informasi yang tepat guna untuk keperluan pemasangan listrik prabayar. Dalam kesehariannya, PT PLN (Persero) Rayon Lhoksukon melaksanakan pemasangan listrik prabayar ini masih dengan cara manual dan akan membutuhkan waktu yang lama dalam permohonan admistrasi pemasangan listrik prabayar.Sistem informasi pemasangan listrik prabayar baru merupakan sistem informasi yang sudah terkomputerisasi sistemnya, dalam sistem pemasangan listrik baru admin menginputkan data pemohon yang ingin memasangkan listrik baru dirumahnya secara otomatis ke database dan memudahkan admin dalam pencarian data di kemudian hari. Jika sistem nya belum terkomputerisasi dan hanya manual saja nantinya data pemohon masih ditumpuk dalam lemari arsip, sehingga pada saat pembuatan laporan memiliki kesulitan dalam pencarian data pemohon dan memiliki resiko kehilangan data. Hal ini tidak di dukung dengan adanya media penyimpanan berupa sistem database untuk manajemen data pemohon. Berdasarkan hal tersebut maka dengan sistem informasi pemasangan listrik prabayar baru berbasis php dan mysql, ternyata dapat membantu pemohon dalam mendaftar pemasangan listrik dan menjadi sistem penyampaian informasi yang dapat memberikan kemudahan dalam hal pengolahan data pemohon bagi pegawai, khususnya dalam melakukan pengolahan dan juga penyimpanan data pemohon, Adapun tujuan dari sistem informasi ini adalah untuk mendata dan melayani pelanggan untuk mendaftar pemasangan listrik baru dengan struktur.
\end{abstract}

Kata Kunci: Sistem Informasi, Pemasangan, Prabayar, Listrik

\section{Pendahuluan}

Perkembamgan manusia saat ini sangat dipengaruhi oleh perkembangan teknologi informasi yang memungkinkan terjadinya perpindahan data informasi yang sangat cepat [1]. Hal ini menuntut setiap individu atau pun situasi untuk terus mengikuti perkembangan teknologi informasi. Salah satu teknologi informasi yang sangat berkembang saat ini adalah web programming. Sseiring dengan kemajuan dunia ilmu pengetahuan dan teknologi, terutama pada teknologi computer maka kebutuhan terhadap informasi yang tepat dan akurat juga ikut berkembang, computer merupakan pemroses data yang cepat dan akurat didukung dengan berbagai macam pemrogaman yang ada dalam menyajikan informasi terutama di bidang pemrogaman yang berbasis internet.

Aplikasi penggunaan internet [2] pada saat ini telah sampai pada penggunaan internet baik untuk menyimpan data maupun membuat atau menjalankan program yang dapat memudahkan manusia (user) dalam melakukan pekerjaannya.

Dengan demikian maka PT PLN (Persero) Rayon Lhoksukon ini membutuhkan sarana dan prasarana informasi yang tepat guna untuk keprluan pemasangan listrik prabayar. Dalam kesehariannya, PT (Persero) Lhoksukon cabang Lhokseumawe melaksanakan pemasangan listrik prabayar ini masih dengan cara manual dan akan membutuhkan waktu yang lama dalam permohonan admistrasi pemasangan listrik prabayar.

\section{Tinjauan Pustaka}

Pada dasarnya sistem [3] adalah suatu kerangka dari prosedur-prosedur yang saling berhubungan, yang disusun sesuai dengan skema yang menyeluruh untuk melaksanakan suatu kegiatan atau fungsi utama dari perusahaan yang dihasilkan oleh suatu proses tertentu yang bertujuan untuk menyediakan informasi untuk membantu mengambil keputusan manajemen operasi perusahaan dari hari ke hari serta menyediakan informasi yang layak untuk pihak di luar perusahaan. Kata Sistem berasal dari bahasa yunani yang mengandung arti kesatuan atau keseluruhan dari bagian-bagian yang berhubungan satu dengan yang lainnya yang sama [4]. Sistem adalah sekumpulan hal atau kegiatan/elemen yang saling bekerjasama yang dihubungkan dengan cara tertentu sehingga membentuk satu kesatuan untuk melaksanakan suatu fungsi guna mencapai tujuan. 
Menurut [5] secara sederhana sistem dapat diartikan sebagai suatu kumpulan atau himpunan dari unsure, komponen, atau variabel yang terogganisasi, saling berinteraksi, saling tergantung satu sama lain dan terpadu. Struktur sistem merupakan unsur-unsur yang membentuk sistem tersebut. Sedangkan proses sistem menjelaskan cara kerja setiap unsur yang membentuk sistem tersebut. Suatu sistem dapat dirumuskan sebagai setiap kumpulan komponen atau subsistem yang di rancang untuk mencapai suatu tujuan.

Menurut [6] Informasi adalah data yang telah diklasifikasikan atau diolah atau diinterpretasikan untuk digunakan dalam proses pengambilan keputusan. Sistem pengolahan informasi akan mengolah data menjadi informasi atau mengolah data yang tak berguna menjadi berguna bagi yang menerimanya. Nilai informasi berhubungan dengan keputusan. Bila tidak ada pilihan atau keputusan maka informasi tidak diperlukan. Keputusan dapat berkisar dari keputusan berulang sederhana sampai keputusan strategis jangka panjang. Nilai informasi dilukiskan paling berarti dalam konteks pengambilan keputusan.

Sumber dari informasi adalah data [7]. Data merupakan kenyataan yang menggambarkan suatu kejadian serta merupakan suatu kesatuan yang nyata, dan merupakan bentuk yang masih mentah sehingga perlu diolah lebih lanjut melalui suatu model untuk menghasilkan informasi. Jelaslah kiranya data merupakan sumber dari bahan informasi.

Perubahan data menjadi informasi [6] dilakukan oleh pengolah informasi. Pengolaha informasi merupakan salah satu elemen kunci dalam sistem konseptual. Pengolahan informasi menggunakan dapat meliputi elemen elemen komputer, elemen-elemen non komputer atau kombinasinya.

\section{Metodologi Penelitian}

Dari pengamatan langsung ke lapangan dan menganalisa Sistem Informasi pemasangan listrik prabayar baru proses pengelolaan datanya masih menggunakan sistem manual hanya menggunakan Microsoft Excel dan buku agenda sebagai media penyimpanan data dalam lemari khusus pengarsipan. sehingga sering terjadinya duplikat data yang berlebihan serta masalah ini juga dapat menyulitkan para Pekerja dalam pencarian data sebelumnya yang tersimpan secara manual.

Pada sistem baru ini akan di rancang Aplikasi Sistem informasi pemasangan listrik prabayar baru berbasis web. Dengan adanya aplikasi ini maka data informasi pemasangan listrik prabayar baru akan di simpan di database MySQL. Tujuannya adalah untuk memudahkan pekerja dalam mengelola data pemasangan listrik prabayar baru terutama dalam proses pengimputan, edit, dan hapus serta menambahkan data. Selain itu pekerja dapat dengan langsung menginput data pemasangan listrik prabayar baru pada Aplikasi Sistem Informasi tersebut dan otomatis menyimpannya pada database yang hanya di komputer staf database/admin. Pada sistem ini staf maupun pimpinan akan lebih cepat dan efisien dalam mengakses data pemasangan listrik prabayar baru yang ingin di review serta untuk keperluan lain yang menyangkut dengan pemasangan listrik prabayar baru [8].

\section{Hasil Dan Pembahasan}

Perancangan sebuah sistem akan dapat dilakukan setelah analisis sebuah sistem dilewati. Perancangan dapat didefinisikan sebagai penggambaran, perencanaan dan pembuatan sebuah pola atau sketsa dari beberapa elemen yang terpisah kedalam satu kesatuan yang utuh atau sering disebut dengan sebuah interface. Perancangan sistem informasi ini dibangun bertujuan untuk memudahkan para staf dalam mengelola data pemasangan listrik prabayar baru. Karyawan atau staff di kantor PT. PLN Rayon Lhoksukon dapat mengelola data Pemasanagn hanya dengan membuka sistem informasi dan kemudian melakukan pengelolaan data. Perancangan sistem informasi pemasangan listrik prabayar baru berbasis web yang dibangun ini bersifat object oriented (berorientasi objek) dengan menggunakan Diagram Conteks, Data Flow Diagram (DFD), Entity Relationship Diagram (ERD)sebagai bahasa pemodelan.

Diagram konteks merupakan suatu model yang harus menjelaskan secara global bagaimana data digunakan dan ditransformasikan untuk di proses. Diagram konteks ini menjelaskan secara garis besar tentang masukan (input), proses dan keluaran (output) yang dihasilkan dari system yang akan dirancang. Adapun diagram konteks yang di usulkan adalah sebagai berikut :

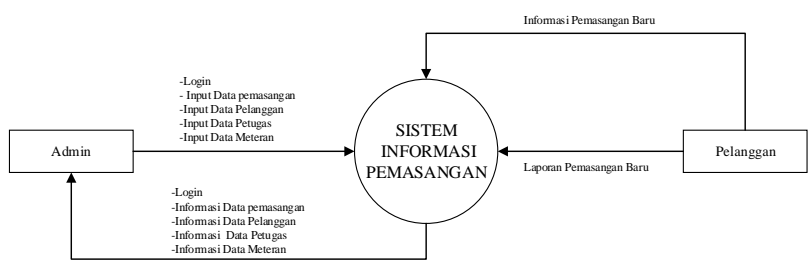

Gambar 1. Diagram Kontek

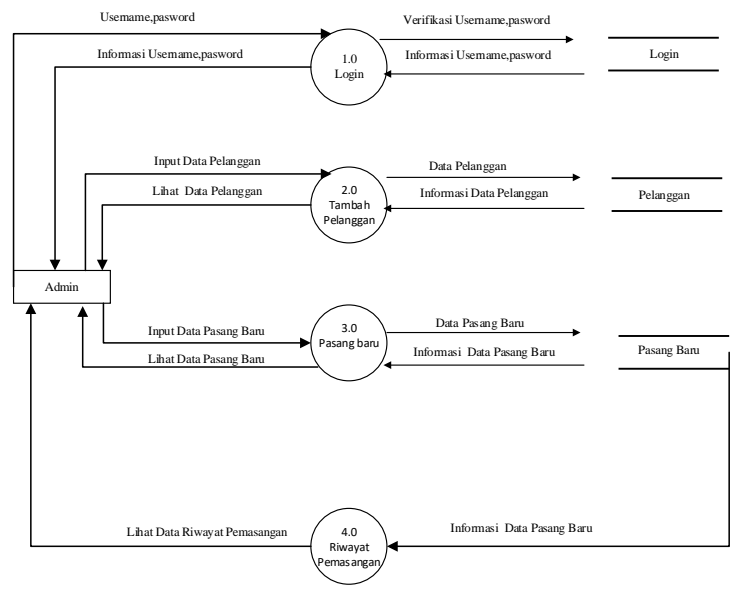

Gambar 2. DFD Level 0 
ERD atau yang lebih dikenal dengan Entity Relationship Diagram digunakan untuk memodelkan struktur data dan hubungan antar data. Pada databse Perancangan Sistem Informasi Penerimaan dan Pengolahan Data monitoring gangguan penyulang inilah struktur data dan hubungan antar datanya. Dari uraian di atas tentang perancangan DFD dapat dibuat sebuah ERD sebagai berikut :

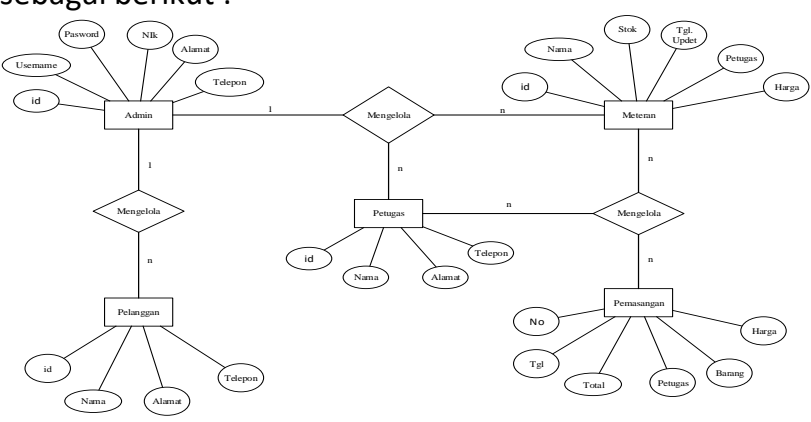

Gambar 3. Entity Relationship Diagram

Implementasi merupakan penerapan sebuah sistem yang telah dianalisa. Langkah implementasi tidak dapat dilakukan sebelum tahap analisa sistem selesai dilalui. Tahap implementasi dimulai dengan proses interface atau desain antar muka sebuah sistem. Desain interface inilah yang akan menjadi wadah penginputan, perubahan dan penghapusan sebuah data yang akan dikelola. Setelah interface selesai dibuat, maka sistem pun akan dapat digunakan. Berikut adalah beberapa interface yang terdapat dalam sistem informasi pengelolaan data.

Halaman Login adalah halaman admin menjalankan aplikasi sistem informasi ini. Form ini berfungsi untuk validasi pengguna sistem. Admin cukup memasukkan username dan password kemudian klik tombol login. Jika berhasil, maka sistem akan menampilkan menu utama. Jika salah, maka memasukkan kembali username dan passwordnya.

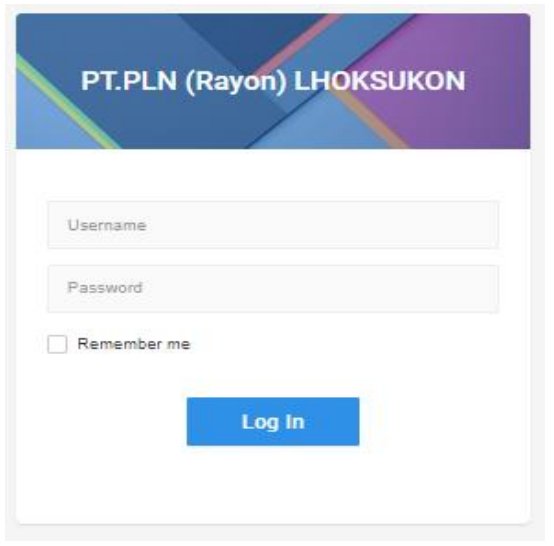

Gambar 4. Halaman Login

Halaman Menu Utama merupakan halaman atau form yang pertama kali muncul ketika program dijalankan. Dimana admin dapat langsung memilih menu yang ingin dikerjakannya. Adapun menu yang tersedia adalah menu beranda, pasang baru, riwayat pemasangan, tambah pelanggan, menu admin dan menu log out untuk keluar dari sistem.

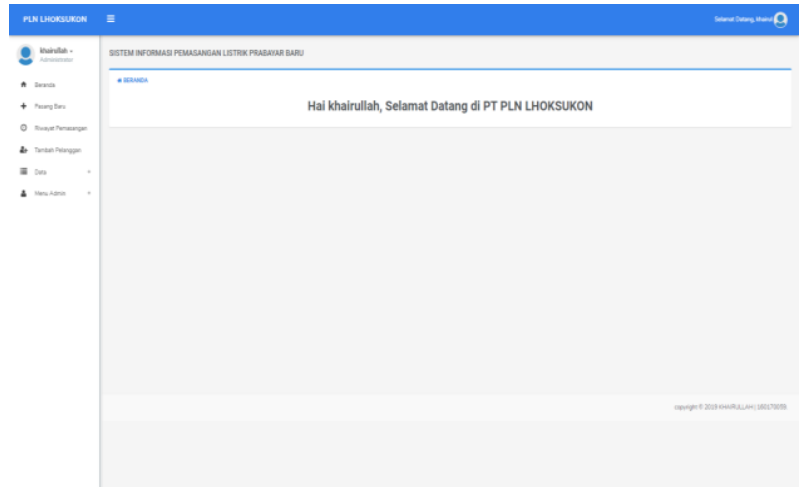

Gambar 5. Tampilan Form Menu Utama

Halaman ini adalah halaman yang dapat diakses oleh admin untuk melakukan pengisian data pemasangan baru. Disini admin dapat memaskukan nama pelanggan yang sudah di input dan melakukan memilih jenis meteran yang diinginkan pelanggan dan berapa unit yang diinginkan , admin juga dapat mengimput tanggal pasang baru,dan mengedit datapemasangan serta hapus data sesuai dengan keperluan.

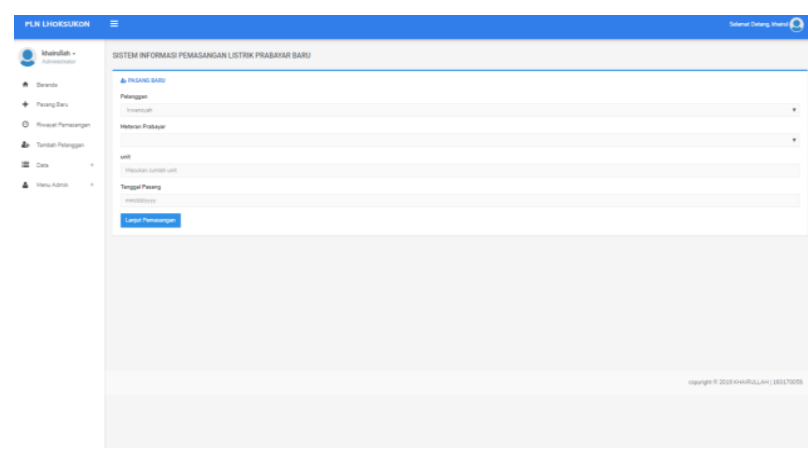

Gambar 6. Tampilan Form Passang Baru

Form riwayat pemasangan adalah sebuah form yang dapat digunakanoleh Adminuntuk melihat riwayat pemasangan meteran prabayar baru. Disini admin juga dapat melihat kwitansi dari pemasangan.

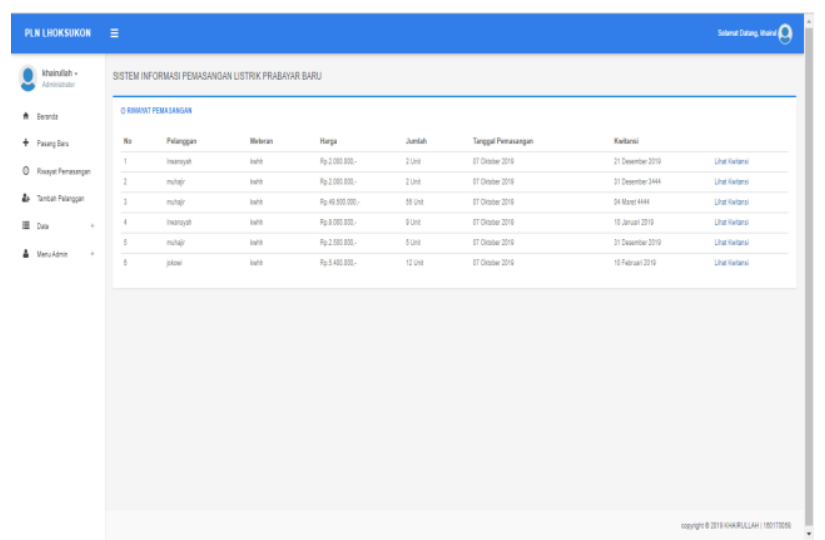

Gambar 7. Tampilan Form Riwayat Pemasangan 
Form tambah pelanggan adalah sebuah form yang dapat digunakanAdmin untuk menginput nama pelanggan ,alamat pelanggan dan nomer telepon pelanggan di simpan di database sistem.

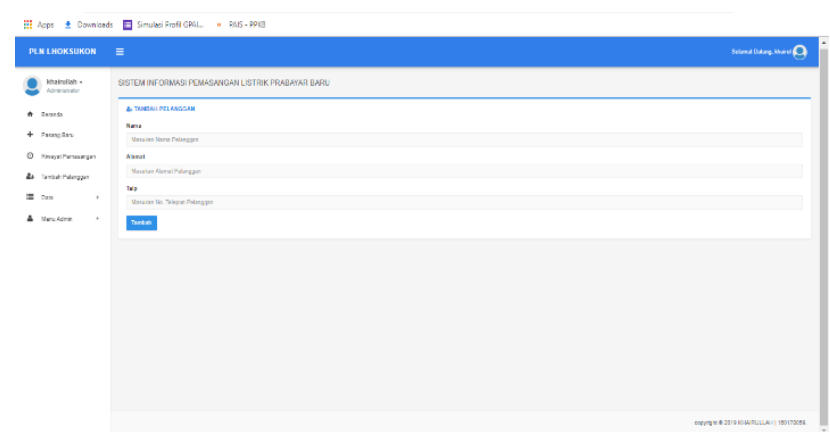

Gambar 8. Tampilan Form Tambah pelanggan

Form data meteran adalah sebuah form yang dapat digunakanAdmin untuk mengimput dan mengupdet nama meteran ,jumlah meteran, harga dan tanggal meteran kemudian akan disimpat ke database.

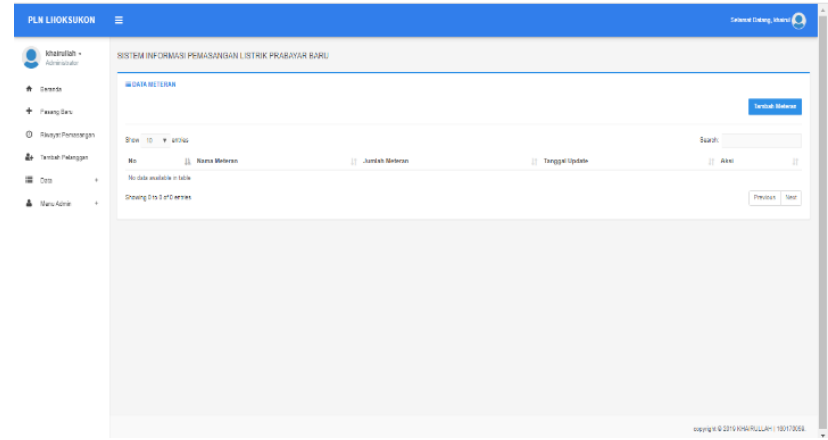

Gambar 9. Tampilan Form Data Meteran

Form data pelanggan adalah sebuah form yang dapat digunakanAdmin untuk mencari nama pelanggan yang sudah dinput dari menu tambah pelanggan.

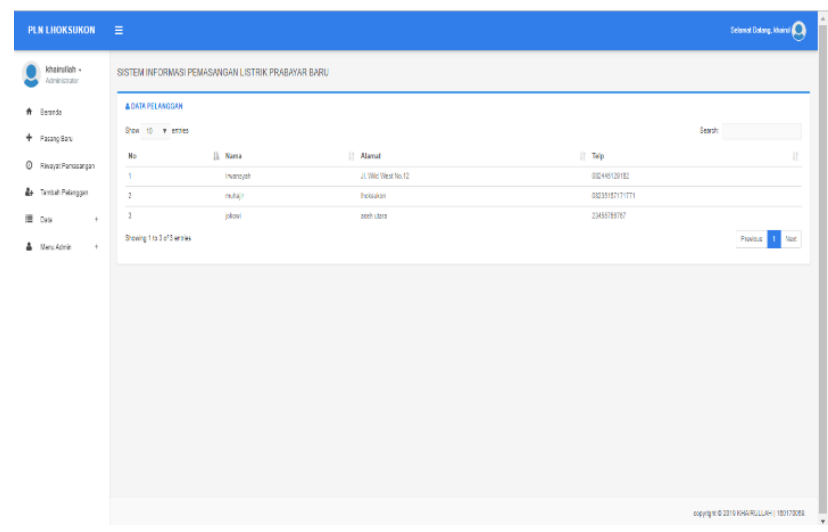

Gambar 10. From Data Pelangan

Form data karyawan adalah sebuah form yang dapat digunakanAdmin untuk melihat nama karyawan yang sudah diinput di menu tambah karyawan.

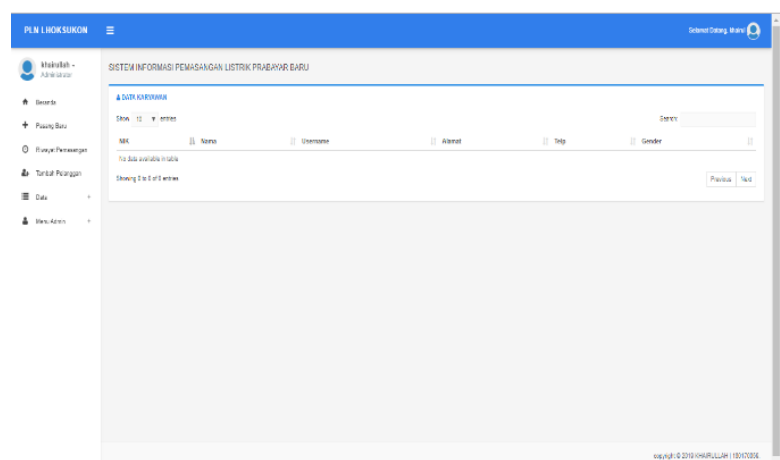

Gambar 11. From Data Karyawan

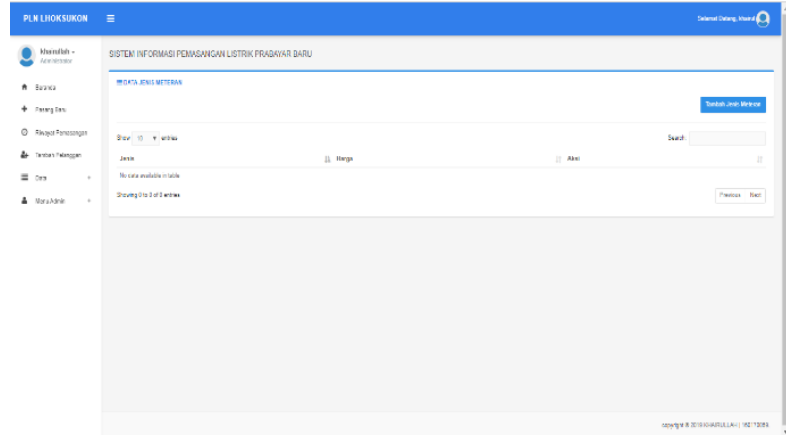

Gambar 12. from data jenis meteran

Form data jenis meteran adalah sebuah form yang dapat digunakanAdmin untuk melihat jenis meteran dan admin juga dapat mengimput jenis meteran baru dan akan disimpan ke database.

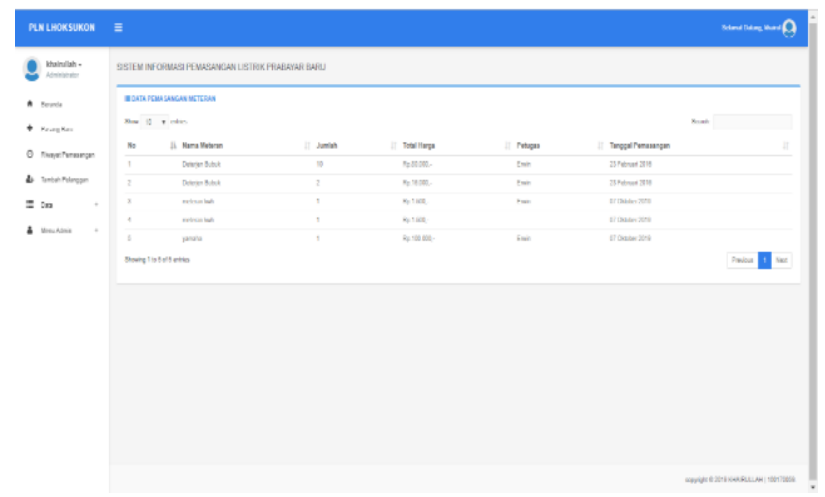

Gambar 13. From Data Pemasangan Meteran

Form data pemasangan meteran adalah sebuah form yang dapat digunakanAdmin untuk melihat data pemasangan.

Selanjutnya Form tambah karyawan adalah sebuah form yang dapat digunakanAdmin untuk menambah nama karyawan baru yang akan bekerja di perusahaan. 


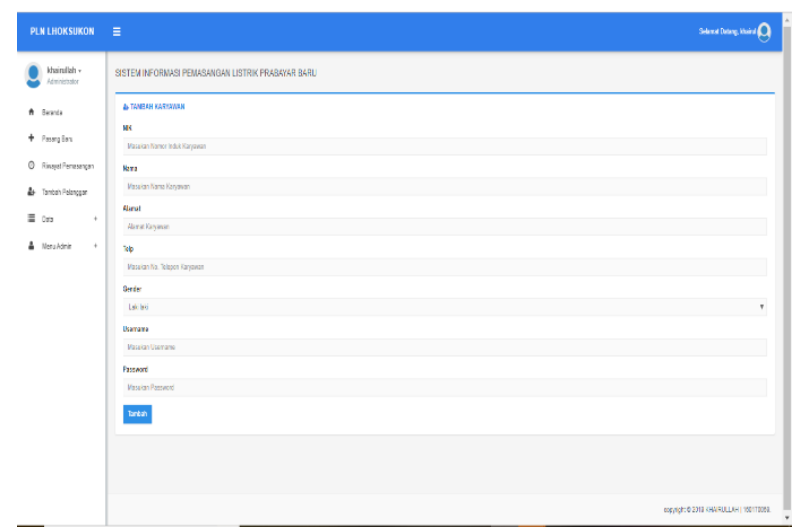

Gambar 14. From Tambah Karyawan

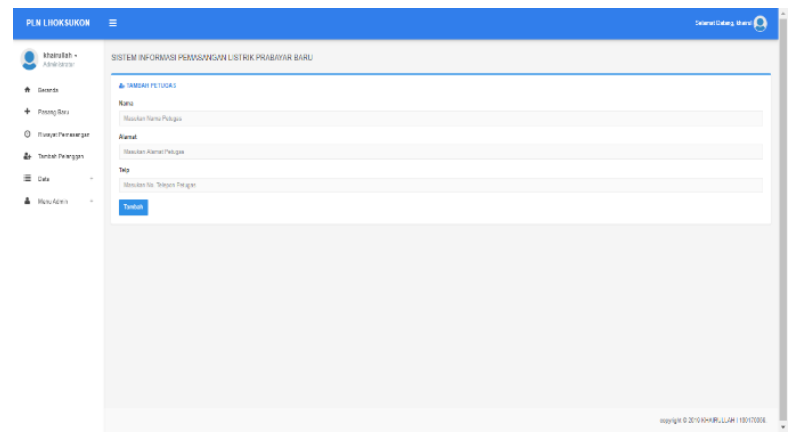

Gambar 15. From Tambah Petugas

Form tambah petugas adalah sebuah form yang dapat digunakan admin untuk menambah data petugas.

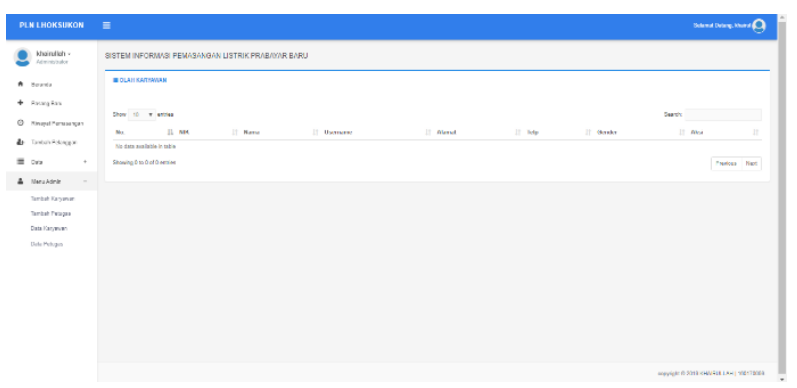

Gambar 16. From Olah Karyawan

Form olah karyawan adalah sebuah form yang dapat digunakan admin untuk mengolah data karyawan dan admin dapat menginput data karyawan dan disimpan ke database.

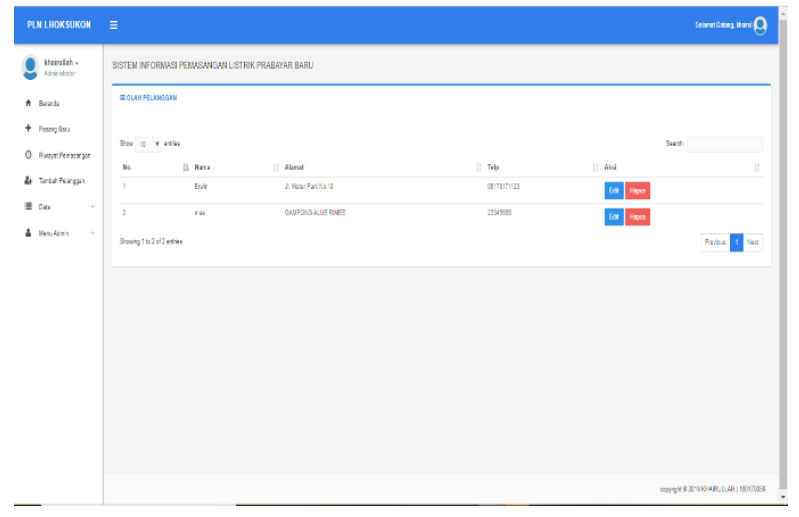

Gambar 17. From Olah Petugas
Form olah petugas adalah sebuah form yang dapat digunakan admin untuk mengolah data petugas dan admin dapat menginput data petugas dan disimpan ke database.

\section{Kesimpulan}

Dari hasil penelitian ini penulis memberikan kesimpulan sebagai berikut :

1. Rancangan Aplikasi Sistem Informasi Pelayanan \& Keluhan Pelanggan di PT.PLN (Persero) Rayon Lhoksukon meliputi DFD, ERD, dan Tabel.

2. Perancangan dari Aplikasi Sistem Informasi Pelayanan \& Keluhan Pelanggan di PT. PLN (Persero) RayonLhoksukon ini dibangun menggunakan PHP sehingga memiliki tampilan yang lebih menarik dan menggunakan database MySQL sehingga pengelolaan database Pelayanan \& Keluhan Pelanggan di PT. PLN (Persero) Rayon Lhoksukon menjadi lebih efektif.

\section{Daftar Pustaka}

[1] S. Wignjosoebroto, A. Rahman, and Y. Endrianta, "Perancangan Tata Letak Fasilitas Produksi dengan Metode Systematic Layout Planning (Studi Kasus Relokasi dan Relayout Pabrik PT . BI - Surabaya)," J. Tek. ITS, 2016.

[2] P. Utomo and F. W. Prayitno, "Perancangan Dashboard Sistem Informasi Untuk Agile Manajemen Proyek dengan Menggunakan JIRA (Studi Kasus: di PT. FLASHiZ Indonesia)," Sisfotek Glob., 2015.

[3] T. Sutabri, "Pengertian / Definisi Android," in Analisis Sistem Informasi, 2012.

[4] Melan Susanti, "Perancangan Sistem Informasi Akademik Berbasis Web Pada Smk Pasar Minggu Jakarta," Informatika, 2016.

[5] T. Sutabri, Analisis Sistem. 2014.

[6] Tata Sutabri, "informasi adalah," kualitas Inf., 2012.

[7] Saifulloh and N. Asnawi, "Data Manajemen Dan Teknologi Informasi," J. IIm. DASI, 2015.

[8] G. F. Fahnani. and M. Karnoto ST, "Transformator daya," Anal. PENGUKURAN DAN PEMELIHARAAN Transform. DAYA PADA, 2011. 